\title{
The Role of Cause Involvement and Assortment Size on Decision Difficulty via Communal Relationships
}

\author{
Claire Heeryung Kim ${ }^{1, *}$ and Joonkyung Kim ${ }^{2}$ (D) \\ 1 Desautels Faculty of Management, McGill University, Montreal, QC H3A 1G5, Canada \\ 2 Independent Researcher, Thornhill, ON L4J 8E8, Canada; joon.kim.research@gmail.com \\ * Correspondence: claire.kim@mcgill.ca
}

check for updates

Citation: Kim, C.H.; Kim, J. The Role of Cause Involvement and Assortment Size on Decision Difficulty via Communal Relationships. Sustainability 2021, 13, 13458. https://doi.org/10.3390/ su132313458

Academic Editor: Andrea Pérez

Received: 2 November 2021

Accepted: 2 December 2021

Published: 5 December 2021

Publisher's Note: MDPI stays neutral with regard to jurisdictional claims in published maps and institutional affiliations.

Copyright: (c) 2021 by the authors. Licensee MDPI, Basel, Switzerland. This article is an open access article distributed under the terms and conditions of the Creative Commons Attribution (CC BY) license (https:/ / creativecommons.org/licenses/by/ $4.0 /)$.

\begin{abstract}
Social enterprises aim to achieve both social and economic goals by reaching broader consumer segments through extensive assortments, but research into how this product proliferation strategy affects consumer response is scarce. In the current research we examine how consumers judge social enterprises providing large product assortments. Three experiments show that choice overload (i.e., having a decision difficulty when faced with many options) can be reversed among target consumers of social enterprises-specifically those whose involvement in a social cause is high. Because more-involved consumers view large assortments of cause-related products as an indicator of the company's commitment to addressing social issues, they identify with the company and thereby form communal relationships. Thus, the consumers' focus shifts from comparing options to helping the company, leading to reduced decision difficulty. The findings contribute to existing research on assortment size and the understanding of the information consumers use to evaluate the company's commitment to social causes.
\end{abstract}

Keywords: social enterprise; decision difficulty; cause involvement; assortment

\section{Introduction}

Over recent years, social enterprise, whose primary mission is to contribute to social causes through a market-driven approach, has been recognized as an innovative way to increase societal well-being. Examples of social enterprise retailers include Warby Parker (provides glasses to people in developing countries with partner VisionSpring), TOMS (gives one third of net annual profit to people in need), and Cafe Direct (gives 50\% of profit to charity to improve the livelihoods of local farmers). While social enterprises address social issues, they also aim to retain profit. Thus, it is vital for social enterprises to gain customer support to achieve their economic and social goals [1,2]. Increasing the size of the selection is one strategy to gain consumer support because a large assortment (i.e., the number of products offered by an organization) can attract broader consumer segments [3]. This strategy becomes more feasible as digital platforms enable extensive assortments [4]. Yet, providing a large assortment can lead to choice overload, as evidenced by previous literature [5]. Large (vs. small) assortments can lead to increased decision difficulty [6], one of the key drivers of decision avoidance, such as choice deferral [7]. In the current research, however, we propose that cause involvement (i.e., perceived relevance of social causes [8]) can reverse choice overload in the context of a social enterprise because the number of products contributing to a cause signals the social enterprise's commitment to the cause.

In particular, we contend that a large (vs. small) assortment will decrease decision difficulty among consumers who perceive supporting social causes as personally relevant and important (i.e., consumers with high cause involvement) because the consumers form a stronger communal relationship with the social enterprise. As a large assortment of products can reflect a social enterprise's commitment and ability to contribute to a cause, consumers with high cause involvement perceive they share a similar goal (i.e., solving a social issue) and consequently form a stronger communal relationship with the company. 
In this communal relationship, individuals are willing to incur costs to respond to the other's needs and do not expect specific compensation [9]. Thus, more-involved consumers will focus more on supporting the social enterprise than on comparing options in the face of a large (vs. small) choice set. This shift in focus may result in a reversal of choice overload. Conversely, less-involved consumers will experience increased decision difficulty when confronted with larger sets because they require more cognitive effort to evaluate options [10,11], displaying choice overload. Even though in the current research we examine consumers' responses with low cause involvement, the focus is on consumers with high cause involvement, as targeting socially conscious consumers and building a relationship with them is an integral part of social enterprises' marketing practice [12].

The present research contributes to the literature in several notable ways. First, we address an important strategic decision that a manager must make: assortment size. Despite an increased interest in social enterprises, scant research exists on the impact of assortment size on consumer perceptions. Second, this research is the first to furnish evidence on how assortment size interacts with an individual's values (i.e., cause involvement) to predict decision difficulty. Thus, it enriches the present theoretical understanding of the nexus between assortment and decision difficulty in that we articulate when choice overload is mitigated or reversed. Last, by showing that the interactive effect of assortment size and cause involvement on decision difficulty is mediated by communal relationships, we provide new insights into a psychological mechanism. Whereas the mainstream of research demonstrates choice overload, we identify an instance in which a large set can lead to reduced decision difficulty because of enhanced perceptions of communal relationships with the social enterprise.

\section{Conceptual Framework}

\subsection{Social Enterprises and Assortment Size}

Social enterprises are "organizations that address a basic unmet need or solve a social or environmental problem through a market-driven approach" [13]. Although social enterprises share similarities with for-profit companies, they are different in that one of their principal missions is to solve social problems, such as environmental pollution, limited employment opportunities, and poor living conditions among disadvantaged groups [14-16]. They also differ from nonprofit organizations in that they use business models to raise funds for their cause and have more autonomy [17]. Hence, social enterprises seek to balance the dual objectives of achieving economic and social goals.

To obtain their economic goals, companies tend to carry large assortments because they cover broader consumer segments [3]. Though large assortments give consumers greater freedom of choice and flexibility [18], they increase decision difficulty [5] because the amount of available information on options increases $[19,20]$ and fears of not choosing the optimal option are induced [21,22]. For example, consumers who selected a chocolate from 30 options felt the decision process was more difficult and frustrating than did consumers who chose from a limited set of six options [6]. When there are many options to choose from, consumers go through a greater number of comparisons to find the best option, which increases the cognitive effort that goes into making the choice [10,11]. As decision difficulty is closely related to the cognitive effort required to process many options $[19,20]$, previous literature has suggested moderators that reduce cognitive effort or direct the focus of effortful comparison [10,23-25]. Extending the literature on moderators of choice overload, we investigate cause involvement as a potential moderator in the context of social enterprise. In particular, we propose that when confronted with a large (vs. small) choice set offered by a social enterprise, consumers with high cause involvement will experience lesser decision difficulty, and the perceived communal relationship will mediate this relationship. 


\subsection{The Interactive Role of Cause Involvement and Assortment Size in Decision Difficulty via Communal Relationships}

Cause involvement refers to the degree to which consumers perceive a social cause as personally relevant and important. Involvement in a cause depends on personal values, situations, and past experiences [8]. Satisfying consumers with high cause involvement is critical for social enterprises because building a relationship with them is an essential part of their marketing practice $[26,27]$.

Consumers often infer commitment levels using cues that reflect the cost the company expends on supporting social causes [28,29]. For instance, the perceived commitment of a company to a cause increased when it had supported the cause for a longer time frame [28] or when the cost of cause marketing was relatively high to the company [29]. Based on these findings, we posit that consumers may use the number of products (i.e., assortment size) as a cue for the company's commitment to the cause. Large assortments incur greater development and production costs in general [30,31], and consumers perceive brands that offer many options in a product category as having greater category expertise [32]. In the context of social enterprise, carrying many products supporting a cause can be seen as a cue for a company's commitment to the social cause. Researchers have found a company's decision to add or delete a cause-related product to influence its perceived attitude toward a cause $[33,34]$. For instance, deleting environment-friendly products from a product line hurts the environmentally friendly image of a company [33]. Thus, a social enterprise with many products whose sales contribute to a social cause can be perceived as committed to addressing the cause.

We propose that more-involved consumers will experience reduced decision difficulty when facing a large (vs. small) choice set offered by a social enterprise because they form a stronger communal relationship with the company. A communal relationship is characterized by a concern for the partner's needs rather than an exchange of comparable benefits [35-37]. Researchers have shown the similarity in attitudes and preferred activities to be essential factors in the attraction and initiation of communal relationships $[38,39]$. According to consumer-company identification theory [40,41], consumers feel a sense of attachment to a company and are attracted to the company when they perceive it has an identity similar to their own $[40,41]$. For example, previous researchers showed that consumers identified themselves with companies performing corporate social responsibility activities, and such customer-company identification resulted in increased customer loyalty $[42,43]$. More-involved consumers are likely to develop a close communal relationship with a social enterprise that is perceived as highly involved in a social cause because of its similarity in values between themselves and the company. Specifically, more-involved consumers will have a communal orientation toward social enterprises that offer many products supporting a cause; these companies are perceived to be strongly interested in social welfare, leading to consumers' identifying with them. In contrast, a social enterprise with few products will not be perceived as particularly interested in or capable of contributing to a cause. Therefore, when more-involved consumers view a small assortment, they will not have as strong a communal relationship with the company as they have with those providing large assortments. They will infer low commitment and feel uncertain about the company's commitment to jointly pursuing a social mission and thus form a weak identification with the company. In sum, more-involved consumers are likely to develop a stronger communal relationship with a social enterprise that provides many (vs. few) products. Consumers who have low cause involvement are not likely to have a communal relationship with a social enterprise because their core values do not overlap with the company's core values concerning social welfare.

The literature on relationship type has demonstrated that communal relationships increase supportive behavior. Individuals in communal relationships are more attentive to others' needs and are more likely to help them because their attitudes and behaviors are guided by communal norms [44]. Importantly, in a communal relationship, consumers are more intrinsically motivated to help the company and show a greater willingness to support 
its efforts toward a cause $[45,46]$. We posit that consumers with a communal orientation are more likely to focus on helping the company rather than comparing individual products in the assortment, leading to decreased decision difficulty. A larger assortment increases decision difficulty partly because it induces more comparisons: evaluating numerous products that involve trade-offs increases cognitive load and decision conflict $[10,24,25,47]$. In line with this mechanism, previous researchers showed that choice overload is mitigated or reversed when the goal of choosing the optimal product is weakened [48-50]. For example, consumers whose focus was on whether to buy instead of selecting a particular product also positively evaluated large assortments [50]. Likewise, consumers exhibited a preference for larger assortments when the focus was on selecting an assortment rather than a single product [49].

Similarly, perceptions of a communal relationship will mitigate the focus on comparing individual products by shifting the focus to helping the company. Moreover, consumers will be less worried about choosing an inferior product because buying a product from a social enterprise will contribute to the social cause regardless. The burden of risk from choosing an inferior product would be reduced, eventually decreasing decision difficulty [51]. Conversely, when more-involved consumers view a social enterprise with few (vs. more) products, they will not be motivated to the same extent to help the company as they would; thus, they will establish a weaker communal relationship. Taken together, we propose that more-involved consumers will experience lower decision difficulty when making a purchase decision from a social enterprise offering a large (vs. small) assortment. Additionally, we propose that a larger assortment size will not decrease decision difficulty among consumers with low cause involvement. Regardless of assortment size, less-involved consumers are not likely to have a communal orientation toward a social enterprise because they do not share an interest in a social issue. Instead, the choice will be for themselves, and the larger assortment size will increase the difficulty they experience while making the choice. Thus, we formally hypothesize the following (see Figure 1 for a theoretical framework):

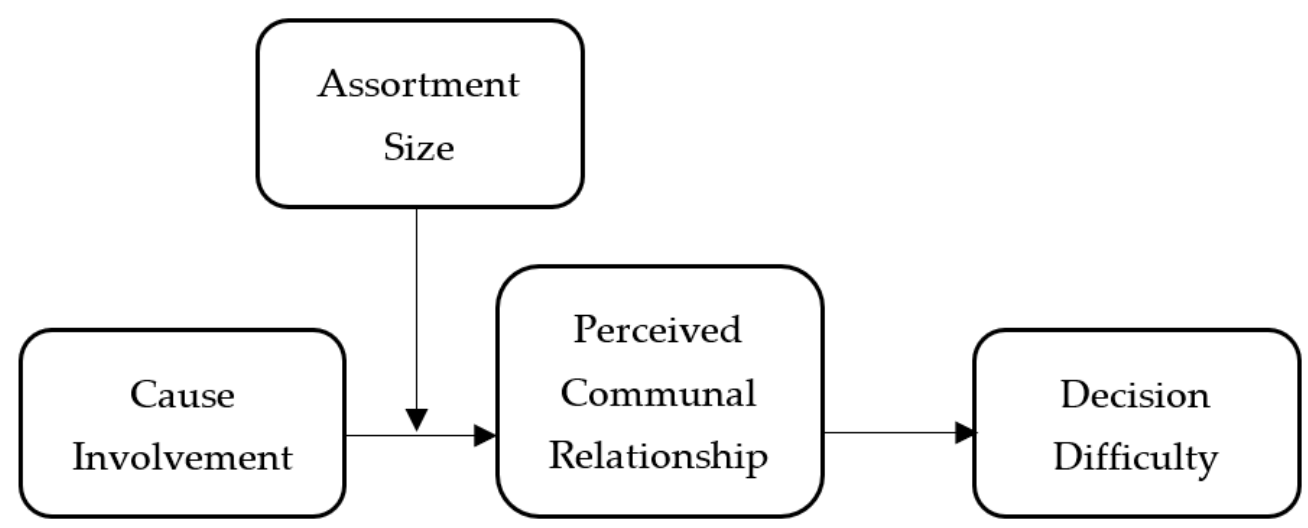

Figure 1. Theoretical Model.

Hypothesis 1 (H1). Individuals with high cause involvement will experience less decision difficulty when assortment size is large (vs. small). Conversely, individuals with low cause involvement will experience greater decision difficulty when assortment size is large (vs. small).

Hypothesis 2 (H2). The interactive effect of assortment size and cause involvement on decision difficulty will be mediated by the perceived communal relationship.

\section{Materials and Methods}

In Study 1, we show that individuals with high cause involvement experience reduced decision difficulty when a social enterprise offers a large (vs. small) assortment. In contrast, choice overload is observed among individuals with low cause involvement. In Study 2, we shed light on the reasons for the observed effects, revealing the mediating role of perceived 
communal relationship. Using secondary data obtained from Kickstarter.com (accessed on 4 November 2020), Study 3 extends the findings by examining how assortment size influences actual behavior among consumers with high cause involvement. To enhance robustness, we used multiple products and dependent variables and used both measured and manipulated cause involvement.

\section{Study 1}

Study 1 tests Hypothesis 1 by examining whether cause involvement interacts with assortment size in the social enterprise domain to determine evaluation difficulty. We predict individuals high in cause involvement will feel lower evaluation difficulty when assortment size is large (vs. small). In contrast, we predict individuals low in cause involvement will experience greater evaluation difficulty in response to larger assortments. To control for confounding effects (e.g., brand familiarity), we used fictitious brands across three product categories.

\subsection{Method}

Two hundred and nine workers from Amazon Mechanical Turk (58.4\% females; $\left.M_{\text {age }}=34.86, S D_{\text {age }}=12.26\right)$ participated in this study for a small monetary compensation. We chose to recruit online panels through Amazon Mechanical Turk to reflect the diversity of the consumers of social enterprise products [52]. They were randomly assigned to one of two groups: large assortment size and small assortment size.

They were first asked to indicate their involvement in supporting social enterprises using four items on a 7-point scale ( $1=$ strongly disagree, $7=$ strongly agree; $M=4.79$, $S D=1.31, \alpha=0.90$; adapted from [8]; see Appendix A). Subsequently, in a seemingly different study, participants conducted an evaluation task for three product categories (pens, t-shirts, and sunglass). Participants in the large (small) assortment condition were presented with large (small) assortments of pens, t-shirts, and sunglasses, consecutively. In the pen evaluation task, participants were told that Company $X$ was a social enterprise that sold a range of stationery products and funded education programs for those in need. Participants were presented with either a large set of 24 options or a small set of six options and were asked to evaluate the products. On the next page, they reported to what extent they felt difficulty in evaluating the given set of products on a 7-point scale: "It was hard for me to evaluate Company X's offerings" ( $1=$ not at all, $7=$ extremely; $M=4.23, S D=1.77)$.

Next, participants engaged in the t-shirt evaluation task. They were told that a social enterprise, Company $\mathrm{Y}$, sold a range of $\mathrm{t}$-shirts made by young, unemployed women in developing countries and that proceeds from the sales went to providing jobs and scholarship opportunities for the women to continue their education and pursue their dreams. Participants saw either a large set of 12 options or a small set of four options and were asked to evaluate the products. On the next page, we measured their perceived evaluation difficulty ("It was hard for me to evaluate Company Y's offerings"; 1 = not at all, $7=$ extremely; $M=3.85, S D=1.85$ ). The set of products was evaluated as a whole.

Last, participants engaged in the sunglass evaluation task. They were told Company $Z$ was a social enterprise that sold sunglasses and worked with nonprofits that trained individuals in developing countries to give basic eye examinations and sell prescription glasses. Participants were provided with either a large set of 24 options or a small set of six options and asked to evaluate the products. On the next page, they reported difficulty in evaluating the given set of products ("It was hard for me to evaluate Company Z's offerings"; $1=$ not at all, $7=$ extremely; $M=4.05, S D=1.84$ ). As we found converging effects across the three product categories, we aggregated the difficulty scores and used the aggregated score as a dependent variable $(\mathrm{M}=4.04, \mathrm{SD}=1.61, \alpha=0.86)$. 


\subsection{Results}

\subsubsection{Manipulation Check}

We conducted a separate test to check the effectiveness of our manipulation of assortment size. One hundred participants from the same subject pool (63.0\% female, $\left.M_{\text {age }}=34.21, S D_{\text {age }}=6.72\right)$ were randomly assigned to see either large or small assortments offered by three social enterprises in a main study. After reviewing each choice set, participants reported the extent to which they felt the company offered many options on a 7-point scale ( 1 = I felt I had too few options, 7 = I felt I had too many options). One-way ANOVAs showed that perceived assortment size was higher when the company offered a large (vs. small) assortment of pens $\left(M_{\text {large }}=5.43, S D=1.62\right.$ vs. $M_{\text {small }}=3.96, S D=1.33$; $F(1,98)=24.49, p<0.001)$, t-shirts $\left(M_{\text {large }}=4.28, S D=1.22\right.$ vs. $M_{\text {small }}=3.06, S D=1.04$; $F(1,98)=28.78, p<0.001)$, and sunglasses $\left(M_{\text {large }}=5.15, S D=1.41\right.$ vs. $M_{\text {small }}=4.09$, $S D=1.02 ; F(1,98)=18.53, p<0.001)$, confirming our manipulations were successful.

\subsubsection{Evaluation Difficulty}

Because cause involvement is a continuous variable, we analyzed the data following Aiken and West [53]. Specifically, we examined the role of assortment size $(0=$ small, $1=$ large) and cause involvement (mean-centered) on evaluation difficulty using a regression analysis. The analysis revealed a main effect of cause involvement $(B=0.59, \mathrm{SE}=0.11$, $t=5.36, p<0.001)$ and a nonsignificant main effect of assortment size $(B=-0.10, \mathrm{SE}=0.21$, $t=-0.49, p=0.61)$. More importantly, a significant interaction between assortment size and cause involvement was found $(B=-0.51, \mathrm{SE}=0.16, t=-3.20, p=0.001)$. As predicted in Hypothesis 1, spotlight analyses showed that a large (vs. small) set decreased evaluation difficulty for more-involved participants $(+1 \mathrm{SD}$ of the mean of cause involvement; $M_{\text {large }}=4.08$ vs. $M_{\text {small }}=4.86 ; t=-2.61, p=0.009$ ). Conversely, a large (vs. small) set increased evaluation difficulty for less-involved participants ( $-1 \mathrm{SD}$ of the mean of cause involvement; $M_{\text {large }}=3.87$ vs. $M_{\text {small }}=3.29 ; t=1.91, p=0.05$; Figure 2), even though it was marginally significant.

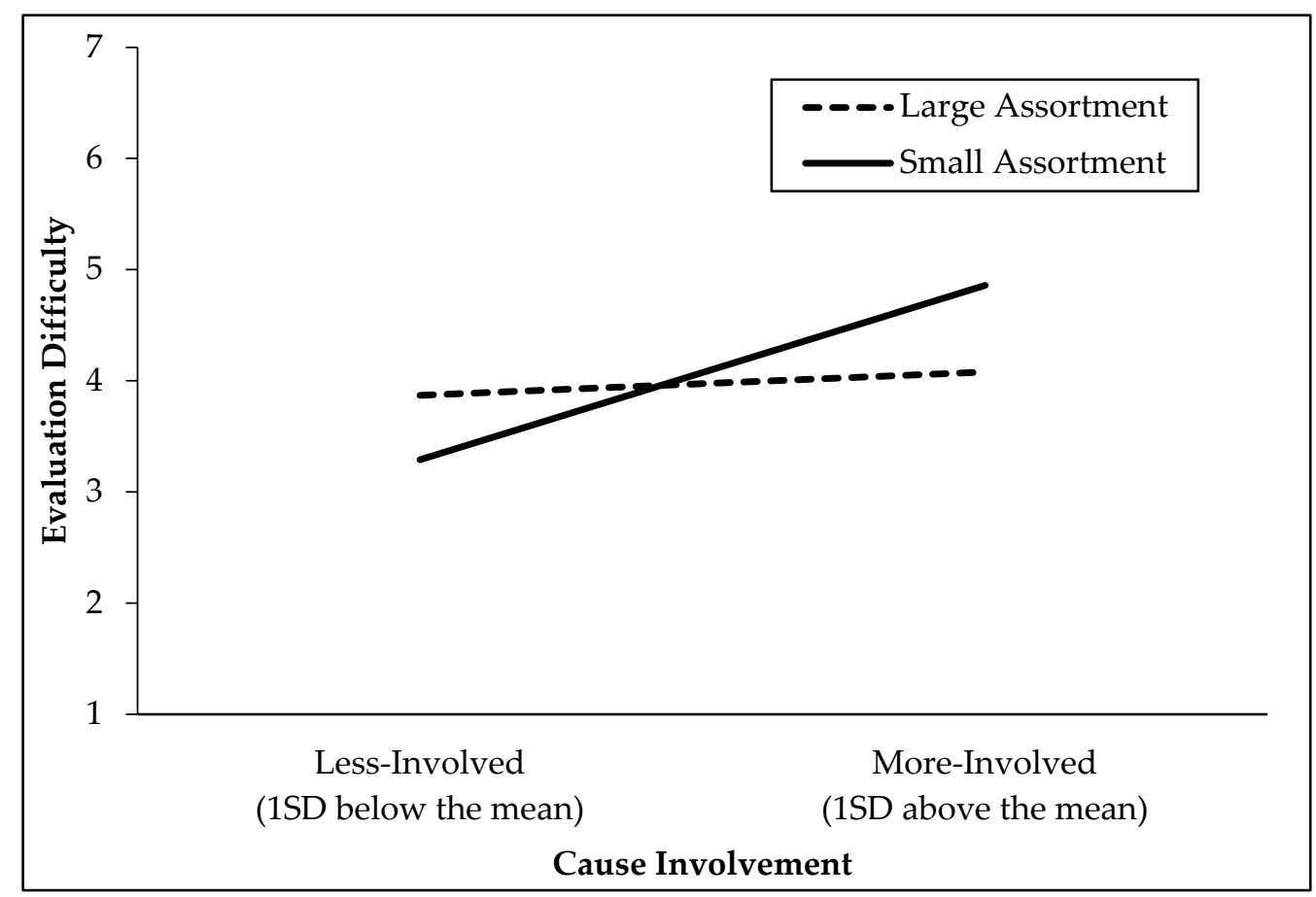

Figure 2. Role of assortment size and cause involvement on evaluation difficulty (Study 1).

Given that cause involvement was a continuous variable, we decomposed the interaction using Johnson-Neyman points [54] and performed a floodlight analysis to examine 
the impact of assortment size on evaluation difficulty across the entire range of cause involvement, as recommended by Spiller, Fitzsimons, Lynch, and McClelland [55]. Using PROCESS Model 1 [56] and the raw scores for cause involvement $(\min =1$, $\max =7$ ), our analysis showed that assortment size influenced evaluation difficulty when cause involvement was high (i.e., $5.51 ; B_{\mathrm{JN}}=-0.46, \mathrm{SE}=23, p=0.05$ ) or low (i.e., 3.43; $B_{\mathrm{JN}}=0.60$, $\mathrm{SE}=30, p=0.05)$.

\subsection{Discussion}

Consistent with our prediction, Study 1 revealed that cause involvement interacts with assortment size to influence evaluation difficulty. Consistent with the extant literature on choice overload, we find that large (vs. small) assortment size increases evaluation difficulty for the less-involved. Conversely, choice overload is reversed when individuals are highly involved in social causes. They experience lower evaluation difficulty when confronted with large (vs. small) choice sets. The weak pattern among the less-involved could have been driven by the fact that individuals low in cause involvement may not have been motivated to input their time and cognitive resources in evaluating products offered by social enterprises. In the next study, we sought to test our posited mechanism by directly examining the mediating role of communal relationship.

\section{Study 2}

The purpose of Study 2 is twofold. First, we seek to gain insight into the process through which assortment size has a negative effect on the perceived difficulty for individuals high in cause involvement. Specifically, we investigate whether a communal relationship mediates the interactive effect of assortment size and cause involvement on decision difficulty. Second, to bolster our claim that there is a causal link between high cause involvement and increased communal relationship with a social enterprise that offers a large (vs. small) choice set, we manipulate high (vs. control) cause involvement.

\subsection{Method}

One hundred and eighty-three workers from Amazon Mechanical Turk (38.8\% female; $\left.M_{\text {age }}=39.54, S D_{\text {age }}=13.89\right)$ were recruited to participate in this study for a small monetary compensation. This study employed a 2 (assortment size: large vs. small) $\times 2$ (cause involvement: high vs. control) between-participants design.

Participants were instructed to complete several unrelated tasks. First, participants were told researchers needed their help in pretesting a sample news article that would be used in a student's thesis. This task involved manipulating the participants' involvement with a social cause. Specifically, participants read about social enterprises (adapted from [57,58]; Appendix B). In the high involvement condition, the role of social enterprises in improving social and environmental well-being were addressed. In the control involvement condition, however, terminology and the history of social enterprises were discussed. After reading the article, in the high involvement condition, participants were asked to answer why the rise of social enterprises and their goals were observed. In the control condition, participants were asked to answer in which country the distinct concept of social enterprise was developed and which two organizations jointly created a forum for social enterprise researchers and practitioners. A pretest with 100 workers from the same subject pool $\left(45.0 \%\right.$ female; $\left.M_{\text {age }}=43.21, S D_{\text {age }}=14.09\right)$ showed this manipulation successfully changed individuals' involvement with social enterprise. We measured cause involvement as in Study 1 on a 9-point scale ( 1 = strongly disagree, $9=$ strongly agree; $M=5.28$, $S D=2.09, \alpha=0.96$ ). Participants in the high (vs. control) involvement condition reported that supporting social enterprises was more important and relevant to them $\left(M_{\text {high }}=5.76\right.$, $S D_{\text {high }}=1.96$ vs. $\left.M_{\text {control }}=4.90, S D_{\text {control }}=2.12 ; F(1,98)=4.30, p=0.04\right)$.

Subsequently, in an ostensibly separate study, we presented the participants with a shopping scenario. Participants were told that a social enterprise, Company A, offered functional t-shirts and employed young, unemployed women in East Africa, to whom 
the proceeds went to extend their jobs and scholarship opportunities. Participants were provided with a large set of 25 options or a small set of six options. They were asked to review the products and make a choice. On the next page, we measured their choice difficulty on a 7-point scale: "It was easy to find a t-shirt that matches my preference from this company" (reverse coded; $1=$ not at all, $7=$ extremely; $M=4.01, S D=2.06$ ). Next, all participants indicated to what extent they formed a communal relationship with the company using two items on a 7-point scale ("I believe I should go out of my way to help this social enterprise" and "I will feel sad if this social enterprise closes"; $1=$ strongly disagree, $7=$ strongly agree; $M=4.21, S D=1.48, \mathrm{r}=0.73$; adapted from Liu and Chang [59]. Finally, participants were presented with the choice set they had viewed previously and answered the manipulation check question on assortment size on a 7-point scale ("I felt ... " $1=\mathrm{I}$ had too few options, 7 = I had too many options; $M=4.67, S D=1.85$ ).

\subsection{Results}

\subsubsection{Manipulation Check}

A $2 \times 2$ ANOVA revealed a significant main effect of assortment size $(F(1,179)=46.49$, $p<0.001$ ) with no other significant effects ( $p$ s $>0.29$ ). Participants in the large condition $(M=5.53, S D=1.49)$ perceived they had more options than those in the small condition $(M=3.86, S D=1.80)$, confirming the successful manipulation.

\subsubsection{Communal Relationship}

A $2 \times 2$ ANOVA revealed a significant interaction effect $(F(1,179)=8.64, p=0.004)$ with no other significant effects $(p s>0.14)$. Consistent with our prediction, pairwise comparisons showed that in the high involvement condition, large assortment size $(M=4.80, S D=1.15)$ increased communal relationship compared to small assortment size $(M=3.86, S D=1.52$; $F(1,179)=9.21, p=0.003)$. However, assortment size did not have significant effects on communal relationship in the control-involvement condition $\left(M_{\text {large }}=3.95, S D=1.59\right.$ vs $\left.M_{\text {small }}=4.27, S D=1.45 ; F(1,179)=1.15, p=0.28\right)$.

\subsubsection{Choice Difficulty}

A $2 \times 2$ ANOVA revealed a significant main effect of assortment size $(F(1,179)=10.81$, $p=0.002)$ and a nonsignificant main effect of cause involvement $(F(1,179)=0.006, p=0.94)$. More importantly, we observed a significant interaction $(F(1,179)=3.98, p=0.04$; Figure 3$)$. As predicted, pairwise comparisons showed that in the high involvement condition, a large (vs. small) choice set decreased choice difficulty $\left(M_{\text {large }}=3.24, S D=1.89\right.$ vs. $M_{\text {small }}=4.78$, $S D=1.52 ; F(1,179)=12.81, p<0.001)$. However, assortment size did not have significant effects on choice difficulty in the control-involvement condition $\left(M_{\text {large }}=3.81, S D=1.96\right.$ vs. $\left.M_{\text {small }}=4.16, S D=2.08 ; F(1,179)=0.75, p=0.38\right)$.

\subsubsection{Mediation Analysis}

To examine whether the interaction of assortment size $(0=$ small, $1=$ large $)$ and cause involvement $(0=$ control, $1=$ high $)$ influenced choice difficulty through communal relationship, we conducted a bootstrapping analysis for moderated mediation (Process Model 8; [56]. The analysis showed that the two-way interaction was mediated by communal relationship as the $95 \%$ confidence interval (CI) for the higher-order interaction did not include zero ( $\mathrm{ab}=-0.65, \mathrm{SE}=0.27,95 \% \mathrm{CI}[-1.2661,-0.1916])$, supporting Hypothesis 2 . Further analyses revealed that, as predicted, among participants primed with high cause involvement, the mediation through communal relationship was negative and significant $(\mathrm{ab}=-0.49, \mathrm{SE}=0.19,95 \% \mathrm{CI}(-0.9178,-0.1526))$, indicating that a larger assortment increased communal relationship and consequently decreased choice difficulty. In the control-involvement condition, however, mediation through communal relationship was not significant $(\mathrm{ab}=0.16, \mathrm{SE}=0.17,95 \% \mathrm{CI}(-0.1393,0.5297))$. 


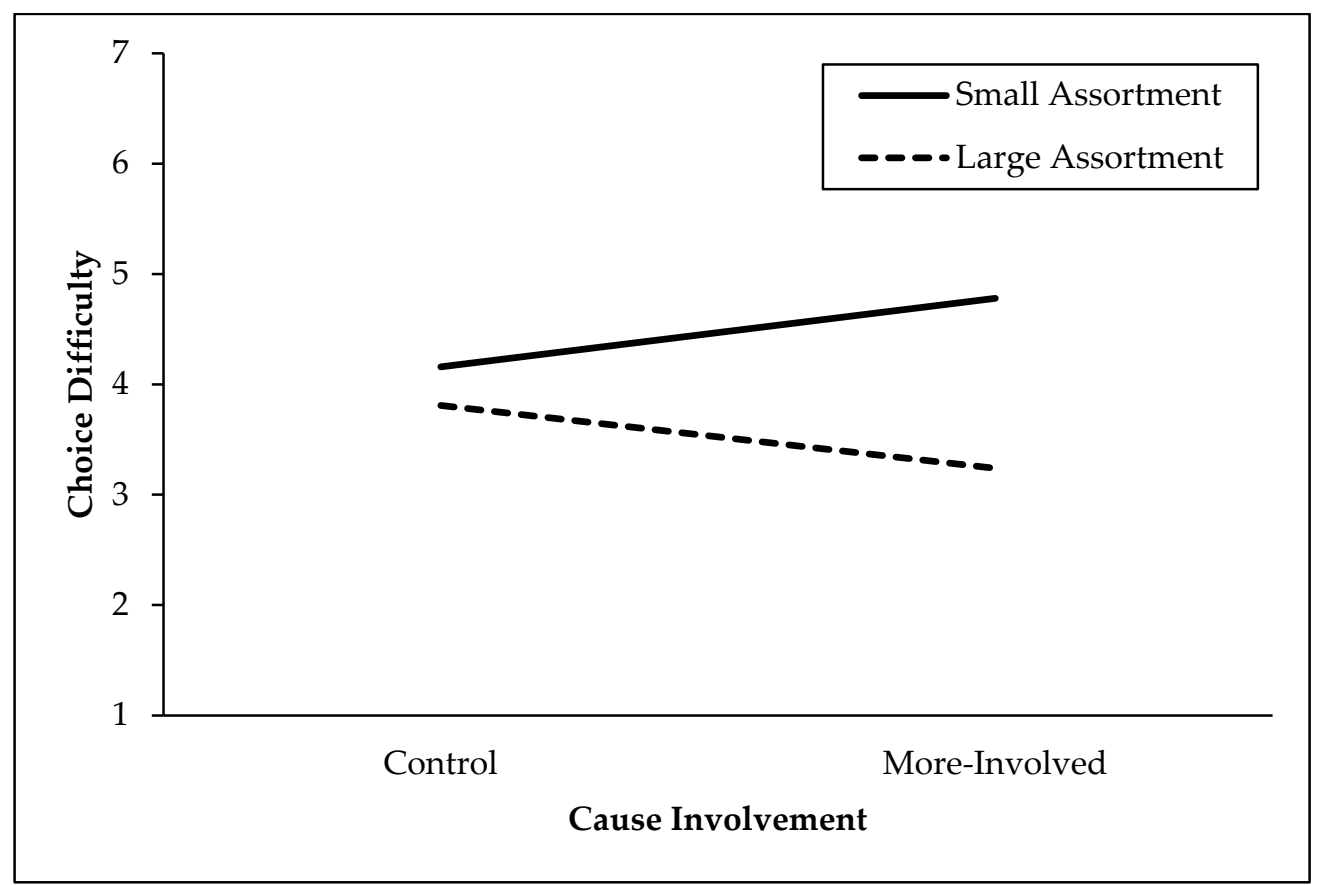

Figure 3. Role of assortment size and cause involvement on choice difficulty (Study 2).

\subsection{Discussion}

These results further support the interaction effect of assortment size and cause involvement on the perceived difficulty in the context of social enterprise. More importantly, these results offer insight into the process via communal relationship through which assortment size and cause involvement jointly affect decision difficulty. In particular, we reveal that a large (vs. small) choice set decreases choice difficulty when individuals have high cause involvement because they establish a stronger communal relationship with the company. While not central to our model, we found a null effect of assortment size on evaluation difficulty among control participants. Since the control participants read an article about social enterprises and why they address social causes, the less-involved may have developed a moderate, not low, level of cause involvement after becoming familiar with the topic. A moderate level of involvement may have attenuated both the negative and positive effects of assortment size on evaluation difficulty.

We argued that assortment size affects perceptions of the firm's commitment in a social cause and consecutively communal relationship. As a post-test, we examined whether consumers infer that a larger (vs. smaller) assortment signals a greater commitment to a cause. We recruited participants from Amazon Mechanical Turk ( $\mathrm{N}=289,37 \%$ female; $\left.M_{\text {age }}=35.03, S D_{\text {age }}=7.86\right)$ who saw the stimuli in Study 2 and reported to what extent they perceived the social enterprise was committed to a given cause $(M=5.36, S D=1.21$, $\alpha=0.95$; see Appendix A). As predicted, participants in the large (vs. small) assortment condition felt a greater commitment of the firm $\left(M_{\text {large }}=5.52, S D=1.12\right.$ vs. $M_{\text {small }}=5.19$, $S D=1.28 ; F(1,287)=5.15, p=0.02)$.

\section{Study 3}

The objective of Study 3 is to examine the influence of assortment size on actual behavior among individuals high in cause involvement to enhance the external validity of our effect. We obtained data from Kickstarter.com (accessed on 4 November 2020), a leading reward-based crowdfunding platform that enables project backers to pledge money to support the development of projects. Project backers tend to pledge money to a project when it is essential to larger society $[60,61]$. Thus, they can be considered individuals high in cause involvement. Usually, project creators provide pledge options varying in fundraising amount and reward for the financial support. By examining the number of 
pledge options and the total funds pledged by project backers, we seek to examine whether assortment size positively affects pledging behavior to a social enterprise among consumers with high cause involvement. We predict that when a project is offered by an owner that has a social mission (i.e., social project), increasing assortment size will lead to an increase in funds from backers.

\subsection{Data}

We collected data on 100 Kickstarter projects whose products were in the fashion category (e.g., clothing, shoes). We first set a goal of including a sufficient number of social enterprises (at least 50) and performed a search using keywords, such as "give back" and "sustainable," that would capture the product owners' social missions. We found 54 projects associated with social missions. The other 46 projects resulted from a search for "clothing" in the fashion category. To verify the search results, two coders reviewed each project description and judged whether the project had a social mission (see Appendix $C$ for detailed coding procedures). During their review, we did not provide the two coders with information about fundraising performance (e.g., amount of funds raised). We reconciled disagreements between the two coders through discussions. Of the 100 projects, we classified 53 as projects with a social mission (i.e., social project) and 47 as projects without (i.e., nonsocial project). All were finished projects at the time of data collection, which was November 2020.

We assessed assortment size using the number of pledge options $(\min =1, \max =40$; $M=9.42, S D=7.34$ ) and pledging behavior using the funds pledged $(\min =0, \max =400,917$; $M=$ USD 16,973, SD = USD 48,744). The number of pledge options was not different between social versus nonsocial projects $\left(M_{\text {social }}=9.17, S D=7.98\right.$ vs. $M_{\text {non-social }}=9.70$, $S D=6.63 ; F(1,98)=0.13, p=0.72)$.

\subsection{Results and Discussion}

Because the number of pledges was a continuous variable, we analyzed the data following Aiken and West [53]. We first applied the log transformation of funds to reduce skewness [62]. After that, we ran a regression with log-transformed funds pledged as the dependent variable and the number of pledge options (mean-centered), project goal ( 0 = nonsocial, 1 = social $)$, and their interaction as independent variables. Regression analysis revealed a main effect of the project goal, such that social (vs. nonsocial) projects increased funds pledged $(B=-0.90, \mathrm{SE}=0.18, t=-04.90, p<0.001)$. More importantly, this main effect was qualified by a significant interaction $(B=0.11, \mathrm{SE}=0.02, t=4.24, p<0.001)$. We did not find the main effect of the number of pledge options $(B=0.02, \mathrm{SE}=0.02, t=1.07$, $p=0.28)$. As predicted, simple slope analyses showed that when a project had a social goal, the higher number of pledge options led to an increase in funds pledged $(B=0.13, \mathrm{SE}=0.01$, $t=8.26, p<0.001)$. When a project did not have a social goal, however, the number of pledge options did not affect funds pledged $(B=0.02, \mathrm{SE}=0.02, t=1.07, p=0.28)$.

The results of Study 3 corroborate our prior findings. Specifically, we demonstrate that the effects of assortment size in the social enterprise context obtained in our previous studies arise in the real world: when a Kickstarter project had a social goal, backers were more likely to pledge money as the number of pledge options increased.

\section{Conclusions}

Social enterprises drastically improve the lives of people in need while making money by applying a business solution to social problems. To do so, they often rely on a strategy of product proliferation, which aims to broaden consumer segments; yet, research on consumer response to assortment size in the domain of social enterprise is scarce. With the present research, we consider the decision difficulty that consumers experience when confronted with choice sets from social enterprises and examine the joint effect of assortment size and cause involvement on decision difficulty. 


\subsection{Theoretical Contributions}

The present research contributes to the literature in three significant ways. First, it adds to the social enterprise literature by addressing a considerable strategic decision that retailers must make. Scant research has examined how the marketing mix of social enterprises affects consumer response, rather than focusing on its impact on organizational performance $[27,63]$. Given that social enterprises have offerings and target customers of a different nature from traditional organizations [12,26,64], it is important to understand how their marketing strategies affect their target customers' responses. Furthermore, existing research on social enterprise marketing has mainly been focused on the role of promotional activities $[12,65,66]$ or pricing [67-69]. To fill this gap, in our research we examine how the product line strategy of social enterprises affects its target customers (i.e., consumers with high cause involvement).

Second, to our knowledge, we offer the first empirical examination of the relationship between assortment size and the consumer's values (i.e., cause involvement). Prior research has suggested that consumers feel greater decision difficulty when confronted with large (vs. small) choice sets because individuals devote more comparison and cognitive effort to their decision-making $[10,11]$. This choice difficulty, however, has been shown to be mitigated or weakened when the focus on comparing individual options or choosing a specific option is shifted to a different goal $[48,49]$. We extend this literature by showing that when consumers consider a social cause to be important, large (vs. small) choice sets decrease decision difficulty. Thus, we confirm that choice overload can be reversed, and cause involvement can determine the effectiveness of a firm's product line strategy.

Last, whereas prior research has explored the role of communal relationships in consumer response to corporate philanthropy [35,45,46], we contribute by identifying assortment size as a determinant of perceptions of communal relationship. Building on consumer-company identification theory [40,41], our results suggest that more-involved consumers identify with a company when it offers extensive assortments because it seems they share values and the goal of supporting social causes. This identification leads consumers to develop a communal relationship with the company, and they focus on helping it rather than choosing the optimal product.

\subsection{Managerial Implications}

This research provides significant implications in retail management for social enterprises and marketers using cause-related marketing. It is essential for social enterprises to communicate their mission in a manner that is acceptable and appealing to target consumers [70], especially those interested in social causes. Addressing the challenge of managing attractive assortments, we offer guidance regarding when consumers view large assortments as appealing. First, our findings show more-involved consumers form a communal relationship with social enterprises that manage many products contributing to a cause, and this relationship decreases the difficulty of choosing from many options. Hence, when targeting highly involved consumers, social enterprise should offer extensive assortments and emphasize their efforts and/or capacity to carry them.

Furthermore, retailers can manage assortments by changing their perceived size, meaning large resources are not necessarily required. Many social enterprises have limited resources as they pursue dual goals [71,72]; thus, strategies that require large company resources may not be feasible. Retailers can increase perception of variety by changing the display of options [73,74], organization of the assortment [75], and grouping options into different categories to highlight their differences [76]. Increasing the perceived assortment size without increasing the number of options may help social enterprises build a communal relationship with target consumers. 


\subsection{Directions for Future Research}

The current research provides opportunities for future research. First, it would be interesting to examine different types of involvement, such as involvement in a product category or decision-making. Consumers involved in a product category may identify with a for-profit company, viewing it as a friend when it provides many products and shows commitment to the product category. Meanwhile, this identification may not occur among consumers involved in decision-making, because such consumers do not necessarily view a product or cause as personally relevant. Further research could generate more insights regarding the role of involvement in reversing the choice overload effect.

Future research may also extend the current findings by exploring how consumers perceive the motivations of social enterprises. Communicating a genuine interest in social causes is essential because consumers skeptical of stated altruistic motivations may negatively view social enterprises. While the number of products related to a cause can communicate a company's genuine interest, merely increasing their number and not contributing to the cause can backfire, instead, signaling greed and leading to adverse effects in consumer response [63]. Hence, future research should examine how firms can manage assortment size to maximize its positive impact.

Author Contributions: C.H.K. and J.K. equally contributed to conceptualization, methodology, software, validation, formal analysis, investigation, resources, data curation, writing, visualization, supervision, project administration, and funding acquisition. All authors have read and agreed to the published version of the manuscript.

Funding: This research received no external funding.

Institutional Review Board Statement: The study was conducted according to the guidelines of the Declaration of Helsinki, and approved by the Institutional Review Board (or Ethics Committee) of McGill University (protocol code 270-1218, Approval date: 18 September 2019).

Informed Consent Statement: Informed consent was obtained from all subjects involved in the study.

Data Availability Statement: All the datasets are available upon request.

Conflicts of Interest: The authors declare no conflict of interest.

Appendix A. Measures

Table A1. Measures in studies.

\begin{tabular}{|c|c|}
\hline MEASURES & STUDIES \\
\hline $\begin{array}{l}\text { Cause Involvement }(1=\text { strongly disagree and } 7 \text { (9 in Study } 2)=\text { strongly agree }) \\
\text { - } \quad \text { Supporting social enterprises is very important for me. } \\
\text { - } \quad \text { Supporting social enterprises is personally relevant to me. } \\
\text { - } \quad \text { Supporting social enterprises means a lot to me. } \\
\text { - } \quad \text { Supporting social enterprises does matter a great deal to me. }\end{array}$ & $\begin{array}{l}\text { STUDIES } \\
1 \& 2\end{array}$ \\
\hline $\begin{array}{l}\text { Assortment Size Manipulation Check Questions } \\
\text { - I felt that .. 1 = I had too few options, } 7=\text { I had too many options }\end{array}$ & $\begin{array}{l}\text { STUDIES } \\
1 \& 2 \\
\end{array}$ \\
\hline $\begin{array}{l}\text { Evaluation Difficulty }(1=\text { not at all, } 7=\text { extremely) } \\
\text { - It was hard for me to evaluate the company's offerings. }\end{array}$ & STUDY 1 \\
\hline $\begin{array}{l}\text { Choice Difficulty }(1=\text { not at all, } 7=\text { extremely }) \\
\text { - It was easy to find a t-shirt that matches my preference from this company. }\end{array}$ & STUDY 2 \\
\hline $\begin{array}{l}\text { Communal Relationship }(1=\text { strongly disagree, } 7=\text { strongly agree }) \\
\text { - } \quad \text { I believe I should go out of my way to help this social enterprise. } \\
\text { - } \quad \text { I will feel sad if this social enterprise closes. }\end{array}$ & STUDY 2 \\
\hline $\begin{array}{l}\text { Firm's Commitment (1 = strongly disagree, } 7=\text { strongly agree) } \\
\text { - } \quad \text { This company can improve the lives of women in East Africa. } \\
\text { - } \quad \text { This company can improve the social status of women in East Africa. } \\
\text { - } \quad \text { This company can help women in East Africa move up in society. } \\
\text { - } \quad \text { This company can offer women in East Africa hope for a better future. } \\
\text { - This company can help women in East Africa have a better life. }\end{array}$ & $\begin{array}{l}\text { POST-TEST } \\
\text { IN STUDY } 2\end{array}$ \\
\hline
\end{tabular}




\section{Appendix B. Cause Involvement Manipulation (Study 2)}

\section{Appendix B.1. High Involvement Condition}

A social enterprise is an organization that applies commercial strategies to maximize improvements in financial, social, and environmental well-being - this may include maximizing social impact alongside profits for co-owners. Social enterprises have both business goals and social goals. As a result, their social goals are embedded in their objective, which differentiates them from other organizations and corporations. A social enterprise's main purpose is to promote, encourage, and make social change. Social enterprises are businesses created to further a social purpose in a financially sustainable way. Social enterprises can provide income generation opportunities that meet the basic needs of people who live in poverty. They are sustainable and earned income from sales is reinvested in their mission. They do not depend on philanthropy and can sustain themselves over the long term. Their models can be expanded or replicated to other communities to generate more impact.

Thus, social enterprises bring the self-sufficiency of for-profit businesses and the incentives of market forces to bear on global social problems in a way that neither pure capitalism nor pure charity has been able to match. There is a great deal of interest in the social enterprise today because this approach offers a new - and possibly more sustainablepath for us to address the world's most pressing challenges. These social enterprises deliver benefits in a self-sustaining way by using their revenues to finance activities that generate social benefit. They can also scale to benefit large numbers of people by incentivizing other players in the value chain and receiving financing from a mix of sources, including consumers, franchisees, patent capital funds like Tandem, and commercial sources.

(source: Barone [57]; Wikipedia [58]).

According to the article, why do we observe the rise of social enterprises?

According to the article, what are the goals of the social enterprises?

\section{Appendix B.2. Control Involvement Condition}

The idea of a social enterprise as a distinct concept first developed in the late 1970s in the UK as an alternative commercial organizational model to private businesses, cooperatives, and public enterprise. The term "social enterprise" has a mixed and contested heritage due to its philanthropic roots in the United States, and cooperative roots in the United Kingdom, European Union, and Asia.

The first international social-enterprise journal was established in 2005 by Social Enterprise London (with support from the London Development Association). The Social Enterprise Journal has been followed by the Journal of Social Entrepreneurship, and coverage of issues pertaining to the social economy and social enterprise are also covered by the Journal of Co-operative Studies and by the Annals of Co-operative and Public Economics. The European Social Enterprise Research Network (EMES) and the Co-operative Research Unit (CRU) at the Open University have also published research into social enterprise. The Skoll World Forum, organized jointly by Oxford and Duke universities, brings together researchers and practitioners from across the globe.

(source: Barone [57]; Wikipedia [58]).

According to the article, in which country was the distinct concept of social enterprise developed?

According to the article, which two organizations jointly created the Skoll World Forum?

\section{Appendix C. Coding Process (Study 3)}

We first selected 100 crowdfunding projects in the fashion category on Kickstarter.com (accessed on 4 November 2020). For each project, a research assistant copied the description of the project, fundraising goal, amount of funds raised, number of reward options, number of backers, currency, and the webpage address. Two coders read the descriptions of the 100 organizations and determined if each organization could be categorized as a social enterprise. They coded an organization as a social enterprise if the project owner explicitly 
mentioned that the organization had a mission to contribute to social welfare and described how the organization was contributing to the social mission. To illustrate, organizations categorized as social enterprises included an organization that donated $25 \%$ of its profits to a partnering nonprofit that provided skills training for recovering addicts. Among the 100 projects, 53 were categorized as social enterprises.

\section{References}

1. Mitchell, A.; Madill, J.; Chreim, S. Social enterprise dualities: Implications for social marketing. J. Soc. Mark. 2016, 6, 169-192. [CrossRef]

2. Roundy, P.T. Doing good while serving customers: Charting the social entrepreneurship and marketing interface. J. Res. Mark. Entrep. 2017, 19, 105-124. [CrossRef]

3. Moorthy, S. Market segmentation, self-selection, and product line design. Mark. Sci. 1984, 3, 288-307. [CrossRef]

4. Mathmann, F.; Chylinski, M.; de Ruyter, K.; Higgins, E.T. When plentiful platforms pay off: Assessment orientation moderates the effect of assortment size on choice engagement and product valuation. J. Retail. 2017, 93, 212-227. [CrossRef]

5. Scheibehenne, B.; Greifeneder, R.; Todd, P.M. Can there ever be too many options? A meta-analytic review of choice overload. J. Consum. Res. 2010, 37, 409-425. [CrossRef]

6. Iyengar, S.S.; Lepper, M.R. When choice is demotivating: Can one desire too much of a good thing? J. Pers. Soc. Psychol. 2000, 79, 995-1006. [CrossRef]

7. Anderson, C.J. The psychology of doing nothing: Forms of decision avoidance result from reason and emotion. Psychol. Bull. 2003, 129, 139-167. [CrossRef]

8. Grau, S.L.; Folse, J.A.G. Cause-related marketing (CRM): The influence of donation proximity and message-framing cues on the less-involved consumer. J. Advert. 2007, 36, 19-33. [CrossRef]

9. Clark, M.S.; Mills, J. The difference between communal and exchange relationships: What it is and is not. Personal. Soc. Psychol. Bull. 1993, 19, 684-691. [CrossRef]

10. Gourville, J.T.; Soman, D. Overchoice and assortment type: When and why variety backfires. Mark. Sci. 2005, 24, 382-395. [CrossRef]

11. Shugan, S.M. The Cost of Thinking. J. Consum. Res. 1980, 7, 99-111. [CrossRef]

12. Allan, B. Social enterprise: Through the eyes of the consumer (prepared for the National Consumer Council). Soc. Enterp. J. 2005, 1, 57-77. [CrossRef]

13. What is Social Enterprise? Available online: https:// socialenterprise.us/about/social-enterprise/ (accessed on 8 January 2020).

14. Defourny, J.; Nyssens, M. Defining Social Enterprise. In Social Enterprise: At the Crossroads of Market, Public Policies and Civil Society; Nyssens, M., Ed.; Routledge: New York, NY, USA, 2006; pp. 3-27.

15. Lumpkin, G.T.; Moss, T.W.; Gras, D.M.; Kato, S.; Amezcua, A.S. Entrepreneurial processes in social contexts: How are they different, if at all? Small Bus. Econ. 2013, 40,761-783. [CrossRef]

16. Easterly, L.; Miesing, P. Social Venture Business Strategies for Reducing Poverty. In Innovative Approaches to Reducing Global Poverty; Stoner, J.A., Wankel, C., Eds.; Information Age Publishing: Charlotte, NC, USA, 2007; pp. 3-26. ISBN 9781593117528.

17. Tsai, J.-M.; Hung, S.-W.; Yang, T.-T. In pursuit of goodwill? The cross-level effects of social enterprise consumer behaviours. J. Bus. Res. 2020, 109, 350-361. [CrossRef]

18. Kahn, B.E.; Lehmann, D.R. Modeling choice among assortments. J. Retail. 1991, 67, 274-299.

19. Timmermans, D. The impact of task complexity on information use in multi-attribute decision making. J. Behav. Decis. Mak. 1993, 6, 95-111. [CrossRef]

20. Fasolo, B.; Carmeci, F.A.; Misuraca, R. The effect of choice complexity on perception of time spent choosing: When choice takes longer but feels shorter. Psychol. Mark. 2009, 26, 213-228. [CrossRef]

21. Iyengar, S.S.; Wells, R.E.; Schwartz, B. Doing better but feeling worse: Looking for the "best" job undermines satisfaction. Psychol. Sci. 2006, 17, 143-150. [CrossRef] [PubMed]

22. Schwartz, B. The Paradox of Choice: Why More is Less; Ecco: New York, NY, USA, 2004.

23. Spassova, G.; Isen, A.M. Positive affect moderates the impact of assortment size on choice satisfaction. J. Retail. 2013, 89, 397-408. [CrossRef]

24. Chernev, A. Product assortment and individual decision processes. J. Pers. Soc. Psychol. 2003, 85, 151-162. [CrossRef] [PubMed]

25. Chernev, A. When more is less and less is more: The role of ideal point availability and assortment in consumer choice. J. Consum. Res. 2003, 30, 170-183. [CrossRef]

26. Facca-Miess, T.M.; Santos, N.J.C. Fostering fair and sustainable marketing for social entrepreneurs in the context of subsistence marketplaces. J. Mark. Manag. 2014, 30, 501-518. [CrossRef]

27. Bandyopadhyay, C.; Ray, S. Social enterprise marketing: Review of literature and future research agenda. Mark. Intell. Plan. 2019, 38, 121-135. [CrossRef]

28. Drumwright, M.E. Company advertising with a social dimension: The role of noneconomic criteria. J. Mark. 1996, 60, 71-87. [CrossRef]

29. De Vries, E.L.E.; Duque, L.C. Small but sincere: How firm size and gratitude determine the effectiveness of cause marketing campaigns. J. Retail. 2018, 94, 352-363. [CrossRef] 
30. Draganska, M.; Jain, D.C. Product-line length as a competitive tool. J. Econ. Manag. Strateg. 2005, 14, 1-28. [CrossRef]

31. Bordley, R. Determining the appropriate depth and breadth of a firm's product portfolio. J. Mark. Res. 2003, 40, 39-53. [CrossRef]

32. Berger, J.; Draganska, M.; Simonson, I. The influence of product variety on brand perception and choice. Mark. Sci. 2007, 26, 460-472. [CrossRef]

33. Bai, C.; Shah, P.; Zhu, Q.; Sarkis, J. Green product deletion decisions. Ind. Manag. Data Syst. 2018, 118, 349-389. [CrossRef]

34. Lombart, C.; Labbé-Pinlon, B.; Filser, M.; Anteblian, B.; Louis, D. Regional product assortment and merchandising in grocery stores: Strategies and target customer segments. J. Retail. Consum. Serv. 2018, 42, 117-132. [CrossRef]

35. Aggarwal, P. The effects of brand relationship norms on consumer attitudes and behavior. J. Consum. Res. 2004, 31, 87-101. [CrossRef]

36. Clark, M.S.; Mills, J. Interpersonal attraction in exchange and communal relationships. J. Pers. Soc. Psychol. 1979, 37, 12-24. [CrossRef]

37. Clark, M.S.; Mills, J.; Powell, M.C. Keeping track of needs in communal and exchange relationships. J. Pers. Soc. Psychol. 1986, 51, 333-338. [CrossRef] [PubMed]

38. Clark, M.S.; Beck, L.A.; Aragón, O.R. Relationship Initiation: Bridging the Gap between Initial Attraction and Well-Functioning Communal Relationships. In APA Handbook of Contemporary Family Psychology: Foundations, Methods, and Contemporary Issues Across the Lifespan; Fiese, B.H., Celano, M., Deater-Deckard, K., Jouriles, E.N., Whisman, M.A., Eds.; American Psychological Association: Washington, DC, USA, 2019; pp. 409-425.

39. Byrne, D. Interpersonal attraction and attitude similarity. J. Abnorm. Soc. Psychol. 1961, 62, 713-715. [CrossRef]

40. Bhattacharya, C.B.; Sen, S. Consumer-company identification: A framework for understanding consumers' relationships with companies. J. Mark. 2003, 67, 76-88. [CrossRef]

41. Bhattacharya, C.B.; Sen, S. Doing better at doing good: When, why, and how consumers respond to corporate social initiatives. Calif. Manage. Rev. 2004, 47, 9-24. [CrossRef]

42. Raza, A.; Saeed, A.; Iqbal, M.K.; Saeed, U.; Sadiq, I.; Faraz, N.A. Linking corporate social responsibility to customer loyalty through co-creation and customer company identification: Exploring sequential mediation mechanism. Sustainability 2020, 12, 2525. [CrossRef]

43. Sun, H.; Rabbani, M.R.; Ahmad, N.; Sial, M.S.; Cheng, G.; Zia-Ud-Din, M.; Fu, Q. Co-creation and green consumer loyalty: Are green banking initiatives important? A moderated mediation approach from an emerging economy. Sustainability 2020, $12,10688$. [CrossRef]

44. Clark, M.S.; Oullette, R.; Powell, M.C.; Milberg, S. Recipient's mood, relationship type, and helping. J. Pers. Soc. Psychol. 1987, 53, 94-103. [CrossRef]

45. Johnson, J.W.; Grimm, P.E. Communal and exchange relationship perceptions as separate constructs and their role in motivations to donate. J. Consum. Psychol. 2010, 20, 282-294. [CrossRef]

46. Bolton, L.E.; Mattila, A.S. How does corporate social responsibility affect consumer response to service failure in buyer-seller relationships? J. Retail. 2015, 91, 140-153. [CrossRef]

47. Tversky, A.; Shafir, E. Choice under conflict: The dynamics of deferred decision. Psychol. Sci. 1992, 3, 358-361. [CrossRef]

48. Chernev, A.; Böckenholt, U.; Goodman, J. Choice overload: A conceptual review and meta-analysis. J. Consum. Psychol. 2015, 25, 333-358. [CrossRef]

49. Chernev, A. Decision focus and consumer choice among assortments. J. Consum. Res. 2006, 33, 50-59. [CrossRef]

50. Gao, L.; Simonson, I. The positive effect of assortment size on purchase likelihood: The moderating influence of decision order. J. Consum. Psychol. 2016, 26, 542-549. [CrossRef]

51. Simonson, I. The effect of product assortment on buyer preferences. J. Retail. 1999, 75, 347-370. [CrossRef]

52. Chandler, J.; Rosenzweig, C.; Moss, A.J.; Robinson, J.; Litman, L. Online panels in social science research: Expanding sampling methods beyond Mechanical Turk. Behav. Res. Methods 2019, 51, 2022-2038. [CrossRef]

53. Aiken, L.S.; West, S.G. Multiple Regression: Testing and Interpreting Interactions; SAGE Publications Inc.: Thousand Oaks, CA, USA, 1991; ISBN 0761907122.

54. Johnson, P.O.; Neyman, J. Tests of certain linear hypotheses and their application to some educational problems. Stat. Res. Mem. 1936, 1, 57-93.

55. Spiller, S.A.; Fitzsimons, G.J.; Lynch, J.G.; McClelland, G.H. Spotlights, floodlights, and the magic number zero: Simple effects tests in moderated regression. J. Mark. Res. 2013, 50, 277-288. [CrossRef]

56. Hayes, A.F. Introduction to Mediation, Moderation, and Conditional Process Analysis: A Regression-Based Approach, 2nd ed.; Guilford Press: New York, NY, USA, 2018.

57. Barone, A. Social Enterprise. Available online: https://www.investopedia.com/terms/s/social-enterprise.asp (accessed on 29 November 2021).

58. Social Enterprise. Available online: https://en.wikipedia.org/wiki/Social_enterprise (accessed on 31 March 2021).

59. Liu, H.-H.; Chang, J.-H. Relationship type, perceived trust, and ambiguity aversion. Mark. Lett. 2017, 28, 255-266. [CrossRef]

60. Aitamurto, T. The impact of crowdfunding on journalism: Case study of Spot. Us, a platform for community-funded reporting. Journal. Pract. 2011, 5, 429-445. [CrossRef]

61. Ordanini, A.; Miceli, L.; Pizzetti, M.; Parasuraman, A. Crowd-funding: Transforming customers into investors through innovative service platforms. J. Serv. Manag. 2011, 22, 443-470. [CrossRef] 
62. Wooldridge, J.M. Introductory Econometrics: A Modern Approach; Cengage Learning: Boston, MA, USA, 2015 ; ISBN 1305446380.

63. Lee, S.; Bolton, L.E.; Winterich, K.P. To profit or not to profit? The role of greed perceptions in consumer support for social ventures. J. Consum. Res. 2017, 44, 853-876. [CrossRef]

64. Shaw, E. Marketing in the social enterprise context: Is it entrepreneurial? Qual. Mark. Res. An. Int. J. 2004, 7, 194-205. [CrossRef]

65. Chung, T.-L.D.; Anaza, N.A.; Park, J.; Hall-Phillips, A. Who's behind the screen? Segmenting social venture consumers through social media usage. J. Retail. Consum. Serv. 2016, 28, 288-295. [CrossRef]

66. Madill, J.; Brouard, F.; Hebb, T. Canadian social enterprises: An empirical exploration of social transformation, financial self-sufficiency, and innovation. J. Nonprofit Public Sect. Mark. 2010, 22, 135-151. [CrossRef]

67. Liu, G.; Eng, T.; Takeda, S. An investigation of marketing capabilities and social enterprise performance in the UK and Japan Entrep. Theory Pract. 2015, 39, 267-298. [CrossRef]

68. Lyon, F.; Ramsden, M. Developing fledgling social enterprises? A study of the support required and means of delivering it. Soc. Enterp. J. 2006, 2, 27-41. [CrossRef]

69. Matei, L.; Sandu, C. Social enterprise towards a marketing approach. Responsib. Sustain. 2013, 1, 51-57.

70. Mallin, M.L.; Finkle, T.A. Social entrepreneurship and direct marketing. Direct Mark. An Int. J. 2007, 1, 68-77. [CrossRef]

71. Austin, J.; Stevenson, H.; Wei-Skillern, J. Social and commercial entrepreneurship: Same, different, or both? Entrep. Theory Pract. 2006, 30, 1-22. [CrossRef]

72. Davies, I.A.; Haugh, H.; Chambers, L. Barriers to social enterprise growth. J. Small Bus. Manag. 2019, 57, 1616-1636. [CrossRef]

73. Kahn, B.E.; Wansink, B. The influence of assortment structure on perceived variety and consumption quantities. J. Consum. Res. 2004, 30, 519-533. [CrossRef]

74. Pizzi, G.; Scarpi, D. The effect of shelf layout on satisfaction and perceived assortment size: An empirical assessment. J. Retail. Consum. Serv. 2016, 28, 67-77. [CrossRef]

75. Hoch, S.J.; Bradlow, E.T.; Wansink, B. The variety of an assortment. Mark. Sci. 1999, 18, 527-546. [CrossRef]

76. Mogilner, C.; Rudnick, T.; Iyengar, S.S. The mere categorization effect: How the presence of categories increases choosers' perceptions of assortment variety and outcome satisfaction. J. Consum. Res. 2008, 35, 202-215. [CrossRef] 